\title{
HALLYU IN AND FOR ASIA
}

\author{
Ju-Yong Ha \\ Inha University \\ hajy85@inha.edu
}

\begin{abstract}
Hallyu has persisted long enough to attain the stature of a major influential cultural phenomenon. Yet the primary locus of exchange appear to be discourses and dialogues produced by Koreans and Western appreciators. What this state of affairs overrides is the reality that the first area of impact of contemporary Korean popular culture is the region immediately outside Korea (and East Asia): the Southeast Asian region. In order to ensure that Koreans and Southeast Asians attain a condition of mutual understanding, scholarship on hallyu vis-à-vis its Asian audiences will have to be facilitated and encouraged.
\end{abstract}

\section{Keywords}

Confucianism, consumption, popular culture, scholarship, Southeast Asia

\begin{abstract}
About the Author
Ju-Yong Ha earned his Ph.D. in Mass Communication \& Media Arts at Southern Illinois University Carbondale in Illinois, US and is currently Professor of Department of Communication and Information at Inha University in Incheon, Korea. His more recent articles have appeared in Asian Studies, Plaridel, Korean Journal of Broadcasting and Telecommunication Studies, and Media Asia.
\end{abstract}


The Korean popular-culture trend now known as hallyu has been around long enough, and has spread widely enough, so that it has assumed certain characteristics that typify global long-term trends. ${ }^{1}$ Fan appreciation is being complemented by scholarly attention, with Korean academics endeavoring to find their own voices amid the global buzz. A growing number of studies on Korean drama, K-pop music, and Korean cinema have been conducted in the wake of such pioneering scholars as Keehyeung Lee, Hyangjin Lee, Kyung Hyun Kim, and Jinhee Choi. ${ }^{2}$

The contention for attention regarding this subject matter generally plays out the same way it does in other non-Western national cultures: between the native subjects and their counterparts in the West. Yet hallyu is one of the still-too-few popular culture trends that originated outside the West, and has an even rarer distinction in being picked up first in a non-Western region in an outward spread of influence: from East Asia, to Southeast Asia, then to the rest of the world.

Certain other properties of a phenomenon of local inception with increasingly overseas reception have come to mark hallyu and its diffusion. ${ }^{3}$ Debates about its zero point tend to vary, depending on what mass medium the arguers are focusing on, although the safest possible answer would be: some time after the 1988 Olympics trained the world's attention on Seoul-only the second time that the Summer Games would be held outside Europe and the Americas, and this time handled by a former colony of the previous Asian sponsor, Japan. (The Beijing Games of 2008 would suggest East Asia as the so-far only Oriental territory capable of hosting Olympic events.)

\section{EXCEPTIONS}

Several speculations on how the East Asian region has been most successful in appropriating the Western developmental model have now become conventional wisdom. Most of these proceed from the Confucian tradition observed by the region. ${ }^{4}$ Reductively expressed, Confucianism's emphasis on secular existence and social hierarchies supposedly meshed with, possibly even enhanced, the call for order and discipline that made industrial development possible.

The significance of Korea within this nexus is overlooked by observers outside of the country itself, although it remains a source of pride within the culture. For among the so-called East Asian dragon nations, Korea is the only one that can lay claim to an unbroken line of Confucian tradition. (We of course need to qualify that the "Korea" of the last century, the source of hallyu, is the South, rather than the socialist North.) 
This, as well as Korea's status as postcolonial nation, may help explain why the products associated with hallyu seem to adhere to conventional premises in terms of formal and ideological treatment, in contrast with the film and music trends from Latin America and the literary and musical contributions from Africa. The postcolonial nature of the rest of the Asian region (excepting East Asia) is also one way of understanding how hallyu could have made such a strong initial impact outside of Korea. Unlike China, whose culture has been dominant (hegemonic, to use a fairly recent term) outside its borders, and Japan, which continues to be remembered as a militaristic aggressor, Korea appears to be recognizable to the other Asian countries in their aspiration to attain developmental success without the "original sin" of occupying and exploiting colonized populations.

\section{PERSPECTIVES}

For this reason, the views of the original "foreign" consumers of hallyu are of more importance than most scholars, even Korean ones, realize at the moment. This is the reason why a collection of articles on contemporary Korean popular culture deserves to focus on the responses of the scholars and audiences of the Southeast Asian region. Although it may seem that Korean experts are more attuned to Western coverage, discourses on hallyu from Southeast Asia have been, understandably enough, ongoing more intensively and for a longer time than they have been in the West. It is high time that such discursive productions result in a dialogue between scholars and policy-makers in Korea, and consumers and academics in neighboring countries; it also necessitates a continuing inquiry into the hallyu phenomenon from this same area beyond the Korean government's "soft-power" motives in disseminating Korean cultural products, as a way of accumulating and developing what we may call first-order global responses.

In the present forum, the study conducted by Mary J. Ainslie, Sarah Domingo Lipura, and Joanne B. Y. Lim, titled "Understanding the Potential for a Hallyu 'Backlash' in Southeast Asia: A Case Study of Consumers in Thailand, Malaysia, and the Philippines," observes a subtle contrast in hallyu appreciation among the member countries of the Association of Southeast Asian Nations: the more developed countries are the ones that experience (for want of a better term) hallyu fatigue. ${ }^{5}$ The study necessarily partakes of quantitative techniques in order to better inform the authors' problematization of emerging resistance to hallyu among its expected consumer groups.

With the cautionary notes from Ainslie et al.s study in mind, we may give ourselves over to recollecting the Korean pop-culture wave via some of its most 
enduring products: its cinema. From the early years, Taeyun $\mathrm{Yu}$ inspects and interrogates samples that impressed themselves directly on the Western imaginary, via European film festivals as well as the art-film distribution circuit. ${ }^{6}$ In "The Matrix of S\&M in Korean Cinema: Time, Space, Trauma, Power," he recapitulates the cultural memory of the Korean War and the Japanese occupation and relates these to the country's own difficult, often violent process of developmental growth, via Ki-duk Kim's Haeanseon [The Coast Guard] and Sunwoo Jang's Ggotip [A Petal]. The two films serve as reminders of how a number of Korean products, while part of the pop-culture production trend, cannot necessarily be distributed with the same guarantees of feel-good family entertainment that accompany "typical" hallyu output.

In fact, in "Remembering the Forgotten War: Origins of the Korean War Film and Its Development during Hallyu," Joel David unearths an entire genre, the Korean-War movie, that underwent the complete genre life-cycle of being produced and attaining some success in tandem with Korean-War film production from Hollywood, then declined and disappeared along with the same trend in foreign cinema, but was revived as if in anticipation of the forthcoming global success of the Korean wave, and flourished as a by-product of the massive profitability of hallyu. David makes a claim for the Korean genre as exceptional in relation to the global war-film canon, but considering how highly circumscribed the attention on hallyu products was, the development was, like successful battle plans, mostly under the radar.

A fairly contemporary film sample, Han Lee's Wan-deuk-i [Punch], connects more closely with Southeast Asian concerns, in the sense that the title character's mother is a migrant wife. Played by Jasmine Lee, who subsequently became the first non-native born Korean to win a seat at the National Assembly, the mother provides a means for the country's foreigners (both migrants and alienated citizens) to witness a process, the unfolding of an intangible and complex emotional condition called han. Maria Luisa Torres Reyes makes the association more understandable by relating it to the Filipino notion of sana-an expression of hopefulness capable of abiding in both past and present, with its attendant emotional component shifting according to circumstances of place and time.

\section{NUANCES}

The present collection takes the vantage point of outside observers and appreciators who are as geographically close to East Asia as it may be possible to get. As mentioned earlier, the identification of Southeast Asians with Korean 
culture plays out differently from their views of the other major cultures of Japan and China. The shape and direction of hallyu ought to take its cue from the other East Asian countries (where its popularity first spread) as well as its final distributive destination, the amorphous West. Yet in a definitive sense, its first true global audience would be Korea's Asian neighbours, so whatever findings show up in the larger region will be of import to Korean cultural policy, as much as hallyu itself has also factored in the decisions of cultural administrations in the rest of Asia.

The larger and longer-term advantage would be the facilitation of dialogues and exchanges between Korea and its neighbours. This would necessitate the use of venues, events, and periodical publications that mark themselves as pop-culture oriented. Hallyu tends to be enriched best by elevated, serious discussion, and enabled its audience to comprehend whatever national agendas the Korean nation needed to disseminate, including an appreciation of its past struggle for democracy as well as its future desire for reunification (Stringer 3, 10). How would Koreans in turn be able to arrive at a state of mutual understanding with their Asian neighbours? No matter how delimiting the use of hallyu could be, the Korean wave could also serve as a window on the world outside, by its built-in ability to generate responses that lead people to discussing it, and in effect, discussing aspects of themselves. 


\section{Notes}

1. Hallyu is a Chinese coinage that means "Korean wave." It refers to the growth of Korean popular culture, from an Asian-regional sensation to a global phenomenon, starting in the 1990s. It first started with Korean TV dramas, then expanded to pop music, and other cultural products. Explanations for its success have been overdetermined, from government intervention in culture production via market protection and the provision of subsidies, through overseas fascination with Korea's transition from Third World to First World status, to the exoticizing appeal of Korean and East Asian cultural values and historical contexts packaged in modern Western media and fashion. For further discussion, see Jeongmin Ko's "Trends and Effects of the Korean Wave."

2. For example, Keehyeung Lee tried to situate hallyu in wider historical, cultural, and transnational contexts.

3. For a short history of hallyu, see Doobo Shim's "Whither the Korean Media?"

4. For a useful summary of the debates (circa early 1990s, with emphasis on Chinese texts), see Jochim's “Confucius and Capitalism” and Tu's “The Rise of Industrial East Asia”; Muhlhahn and Looy's The Globalization of Confucius and Confucianism as well as Tu's Confucian Traditions in East Asian Modernity compile articles that update and expand on these perspectives.

5. Understandably, countries that hallyu first impacted would have displayed earlier signs of fatigue-specifically Korea's East Asian neighbors. Ainslie et al. describe a negative reaction to hallyu in Japan, and later in China and Taiwan as well. Japan, in particular, had been having a long, difficult road to recovery, so although the backlash may be "small but also particularly noisy and visible," it also partakes of such problematic elements as "nationalism, xenophobia and the difficult political legacy of the relationship between Japan and South Korea."-

6. Korean films had always found a global circle of appreciators long before hallyu emerged, but this was owing to the consistent internationalist orientation of film critics and scholars. It might even be possible to speculate that hallyu might suddenly end today, but Korean films will continue to be screened and discussed (along with other representative samples of all other countries) in specialized festivals and university classrooms with film-study programs. Hence these studies of Korean cinema may be considered hallyu in a historical sense, first and foremost, when the films they cite were produced during the hallyu period (i.e., from the 1990 s to the present). One must also keep in mind the special, privileged berth that films occupy: while hallyu may focus attention on them more readily, and provide the means and impetus to source them directly, they belong to a level of preoccupation that provides the technical applications, theoretical systems, and methodologies that other hallyu media (notably telenovelas) draw from.

Kritika Kultura 28 (2017): -062

(C) Ateneo de Manila University

<http://journals.ateneo.edu/ojs/kk/> 


\section{Acknowledgement}

This work was supported by Inha University Research Grant.

\section{Works Cited}

Ainslie, Mary J., Sarah Domingo Lipura, and Joanne B. Y. Lim. "Understanding the Potential for a Hallyu 'Backlash' in Southeast Asia: A Case Study of Consumers in Thailand, Malaysia, and the Philippines." Kritika Kultura, vol. 28, 2017.

Choi, Jinhee. The South Korean Film Renaissance: Local Hitmakers, Global Provocateurs. Wesleyan UP, 2010.

David, Joel. "Remembering the Forgotten War: Origins of the Korean War Film and Its Development during Hallyu." Kritika Kultura, vol. 28, 2017.

Lee, Hyangjin. Contemporary Korean Cinema: Culture, Identity and Politics. Manchester UP, 2000.

Jochim, Christian. "Confucius and Capitalism: Views of Confucianism in Works on Confucian Ethics and Economic Development." Journal of Chinese Religions, 1992, pp. 135-71.

Kim, Kyung Hyun. The Remasculinization of Korean Cinema. Duke UP, 2004.

Ko, Jeongmin. "Trends and Effectives of the Korean Wave." Pop Culture Formations across East Asia, edited by Doobo Shim, Ariel Heryanto, and Ubonrat Siriyuvasak, Jimoondang, 2010, pp. 135-47.

Lee, Keehyeung. "Assessing and Situating 'The Korean Wave' (Hallyu) through a Cultural Studies Lens." Asian Communication Research, vol. 2 no. 2, Sept. 2005, pp. 5-22.

Muhlhahn, Klaus, and Nathalie van Looy, eds. The Globalization of Confucius and Confucianism. LIT Verlag, 2012.

Shim, Doobo. "Whither the Korean Media?" Pop Culture Formations across East Asia, edited by Doobo Shim, Ariel Heryanto and Ubonrat Siriyuvasak, Jimoondang, 2010, pp. 115-33.

Stringer, Julian. Introduction. New Korean Cinema, edited by Chi-Yun Shin and Julian Stringer, New York UP, pp. 1-14.

Torres Reyes, Maria Luisa. "Multicultural Bildungsroman: Coming of Age between Han and Sana." Kritika Kultura, vol. 28, 2017.

Tu, Wei-Ming, ed. Confucian Traditions in East Asian Modernity: Moral Education and Economic Culture in Japan and the Four Mini-Dragons. Harvard UP, 1996.

--. "The Rise of Industrial East Asia: The Role of Confucian Values." Copenhagen Papers in East and Southeast Asian Studies, vol. 4, no.1, Apr. 1989, pp. 81-97.

Yu, Taeyun. "The Matrix of S\&M in Korean Cinema: Time, Space, Trauma, Power." Kritika Kultura, vol. 28, 2017. 
